NON-STANDARD WORKERS: THE SOUTH AFRICAN CONTEXT, INTERNATIONAL LAW AND REGULATION BY THE EUROPEAN UNION

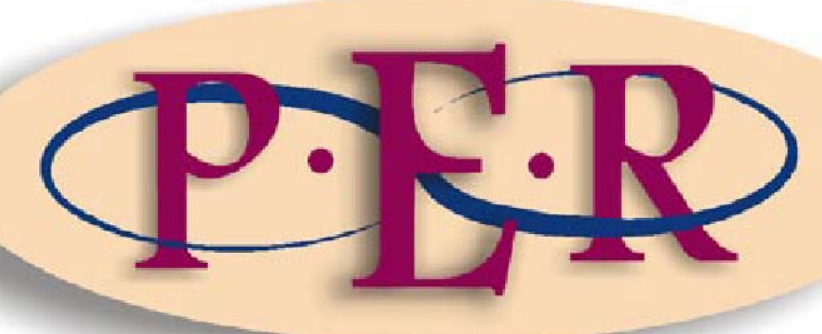

2008 VOLUME 11 NO 4 


\section{NON-STANDARD WORKERS: THE SOUTH AFRICAN CONTEXT, INTERNATIONAL LAW AND REGULATION BY THE EUROPEAN UNION}

ES Fourie*

The current labour market has many forms of employment relations that differ from full-time employment. These include part-time employees, temporary employees, employees supplied by employment agencies, casual employees, home workers and workers engaged in a range of contracting relationships. They are usually described as non-standard or atypical employees. Most of these employees are particularly vulnerable to exploitation because they are unskilled or work in sectors with little or no trade union organisation or little or no coverage by collective bargaining. A high proportion of them are women. They frequently have less favourable terms of employment than other employees performing the same work, as well as less security of employment. Often they do not receive 'social wage' benefits such as medical aid, pension or provident funds. These employees therefore depend upon statutory employment standards for basic working conditions. Most have, in theory, the protection of current legislation, but in practice the circumstances of their employment make the enforcement of their rights extremely difficult. ${ }^{1}$

\section{$1 \quad$ Introduction}

Full-time employment as we know it is changing universally; non-standard employment is increasing and new forms of work are emerging. Globalisation, deregulation and technological advancement, compounded by unemployment, are to blame for the changes in the composition of the workforce. Labour legislation was drafted to protect employees in the traditional full-time employment paradigm and is currently inadequate to provide protection to

* B.PROC (RAU) ADL (RAU) LLM (UJ). Lecturer, Faculty of Law, University of Johannesburg.

1 Department of Labour 1996 http://www.info.gov.za/ 27 Nov. Minimum Standards Directorate Policy Proposals for New Employment Standards Statute Green Paper, February 1996, ch C. (Hereafter Green Paper on Labour). 
workers employed in new forms of non-standard employment. It is becoming a hard task for the courts to distinguish a worker who is not an employee from an employee. The purpose of this article is to explore the scope of the extension of labour rights to non-standard workers in the context of South African labour laws and the international framework. ${ }^{2}$

'Atypical,' 'non-standard', or even 'marginal' are terms used to describe these new workers and to refer to those engaged, for instance, in part-time work, contract work, self-employment, temporary, fixed-term, seasonal, casual, piecerate work, or to employees supplied by employment agencies, home workers and those employed in the informal economy. ${ }^{3}$ These workers are often paid for results rather than time. Their vulnerability is linked in many instances to the absence of an employment relationship or the existence of a flimsy one. Most of these workers are unskilled or work in sectors with limited trade union organisation and limited coverage by collective bargaining, leaving them vulnerable to exploitation. ${ }^{4}$ They should, in theory, have the protection of current South African labour legislation, but in practice the unusual circumstances of their employment render the enforcement of their rights problematic.

The 1996 International Labour Organisation-sponsored (ILO) South African Labour Flexibility Survey (SALFS) was the first significant such survey to indicate that businesses focusing on manufacturing were frequently using temporary and casual workers. The flexibility debate, questioning the appropriateness of the new regulatory regime, arose in South Africa at this time. What concerned employers was the new regulatory framework seen from the perspective of a doctrine of flexibility. ${ }^{5}$ The adoption of 'regulated flexibility'

2 The ILO Conference in 2006 recognised the important role of international organisations to provide guidance to member states regarding the means of achieving protection through national law.

3 Mills 2004 ILJ 1204.

4 Green Paper on Labour, supra n 1, ch 6.

5 Theron 2003 ILJ 1271. 
by the Basic Conditions of Employment $\mathrm{Act}^{6}$ (hereafter the BCEA) clearly reflects government's endeavours to reconcile the concerns of employers with those of organised labour. Clive Thompson commented: "The standard model of employment is now one of inherent variability. Work has changed both for better and for worse." ${ }^{7}$ Since the adoption of progressive labour legislation in South Africa, ${ }^{8}$ employers have camouflaged employment conditions in order to avoid stringent labour laws. ${ }^{9}$

What is this so-called 'employment flexibility'? It simply means that employers, in their quest to reduce costs whilst trying to meet the demands of globalisation, are disregarding the traditional job boundaries - often to the detriment of the unskilled, non-standard worker. ${ }^{10}$ Employers use non-standard workers to avoid restrictive labour laws and collective bargaining restraints. In addition, the practice provides them with more flexibility.

Remedying the situation of most non-standard workers should be relatively easy. It can be achieved by extending minimum floor rights to these workers through legislation, or by strengthening their collective bargaining abilities. ${ }^{11}$ The independent contractor or the employee deemed to be an independent contractor might find him/herself in a more precarious situation, however, as he or she is expressly excluded from the protective ambit of South African labour legislation.

6 Basic Conditions of Employment Act 75 of 1997.

7 Thompson 2003 ILJ 1815.

8 Labour Relations Act 66 of 1995, Basic Conditions of Employment Act 75 of 1997, Employment Equity Act 55 of 1998 and the Constitution of the Republic of South Africa, 1996.

9 Benjamin 2004 ILJ 789.

10 Mills, supra n 3, 1210.

11 Ibid, 1205. 


\section{Some forms of non-standard employment}

\section{$2.1 \quad$ Part-time work}

Part-time employees are employed on an on-going basis, work fewer than standard hours of work, and are predominantly women. Permanent part-time work has more to offer and for female employees this can offer the flexibility they need in order to be able to deal with family responsibilities. The basic norm should be that all employees, including those in this category, are protected by employment standards and at least receive benefits on a proportional basis. ${ }^{12}$

\subsection{Casual and seasonal work}

Though the phrase 'casual work' is often used to refer to all forms of nonstandard work, it applies in fact to workers who are employed in irregular employment. In other countries this type of work is known as 'day labour'. Casual workers are often found in labour-intensive sectors such as the retail, domestic and agricultural sectors. One retail outlet uses the concept 'permanent casuals' to describe their casual workers, indicating that they often work for years for a specific outlet. ${ }^{13}$

This category of worker is left with limited legislative protection. Casual work has obvious disadvantages and is the most severely affected form in terms of lack of protection, especially as regards job insecurity. Casual work is of a temporary nature, and income and availability are uncertain. These jobs are created mostly in low-paid occupations and present few opportunities for the training that would offer the hope of advancement, as employers would rather

12 Green Paper on Labour, supra n 1, 10. Eg, an employee who works from 08 h00 until 13 h00 should receive $5 / 8$ of all benefits. See par 6.2.1 and art 5 of the ILO Part-Time Work Convention of 1994. The Employment Promotion and Protection against Unemployment Convention of 1988 provides in art 10(3) that members shall endeavour to provide the payment of benefits to part-time workers who are seeking full-time work.

13 Bezuidenhout et al "Non-standard employment" 1. A report submitted to the Department of Labour, 30 June 2003. Research undertaken by Sociology of Work Unit, University of the Witwatersrand and Labour and Enterprise Project, University of Cape Town. 
train permanent employees. ${ }^{14}$ Casual labour does, however, provide the advantage of flexibility for a female worker with family commitments.

In South Africa these workers enjoy differentiated protection, as full protection is offered by the Labour Relations Act 66 of 1995 (hereafter the LRA), but limited protection by the BCEA. A casual employee was defined in terms of the previous $B C E A^{15}$ as an employee not working more than 3 days a week. Section 6 of the current Act now excludes only workers who work less than 24 hours a month and at least protection is extended to many casual workers who were previously excluded. Workers who work more than 24 hours per month will be entitled to maternity leave, according to the BCEA. ${ }^{16}$

Seasonal workers are normally employed for the duration of a season, often on fixed-term contracts, as many of them return season after season.

\subsection{Homework}

Homework is not an easy concept to define. It is a form of subcontracting and refers to work that is home-based and involves an employment relationship. ${ }^{17}$ According to the ILO Homework Convention, ${ }^{18}$ it is work undertaken on contract from home. In the clothing industry, this will be a contract with an intermediary rather than with the manufacturer supplying the work. ${ }^{19}$ It is evident that the difficulty in this case lies not identifying the worker but the employer. A distinctive characteristic of this form of work is that the workplace is the worker's home. This form of work is also predominantly done by female workers, in order for them to be able to accommodate their domestic needs.

\footnotetext{
14 Thompson, supra n 7, 1803.

15 Basic Conditions of Employment Act 3 of 1983.

$16 \mathrm{~S} 25$ of the Basic Conditions of Employment Act 3 of 1983. This is a core right and cannot be varied by any agreement unless the terms are more favourable.

17 Godfrey et al 2005 "On the outskirts" 6.

18 ILO Homework Convention 177 of 1996.

19 Theron, supra n 5, 1253.
} 
This form of work creates a serious challenge to labour regulation and organisation. $^{20}$ The LRA provides for bargaining councils to extend their services to home workers, ${ }^{21}$ but bargaining councils have difficulty in enforcing minimum standards due to the concealed nature of homeworking. These workers are difficult to locate and organise and developing common collective issues and demands is problematic. ${ }^{22}$

\subsection{The independent contractor}

The independent contractor is expressly excluded from the definition of an employee contained in South African labour and social legislation ${ }^{23}$ and disguised employment is a significant reality in South Africa. How do the courts determine when an employee is an independent contractor? In South Africa the dominant impression test is still the prevailing test used by courts and arbitrators to determine who is an employee. ${ }^{24}$ The courts in the Mckenzie ${ }^{25}$ case used the dominant impression test and Brassey ${ }^{26}$ criticised this test, indicating that it means nothing more than a decision taking into consideration all relevant factors. In the Medical Association case, ${ }^{27}$ Judge Zondo, president of the Labour Court and the Labour Appeal Court, stated that using the dominant impression test creates uncertainty, but did not consider it necessary to decide the matter on a different basis.

20 In Canada, a proposal for legislative reform for homeworkers entails a notion of joint and several liability to hold retailers and manufactures legally liable for the violations of labour rights. Provision is made for anonymous complaints about rights violation as well as a registration system for employers hiring these workers and more effective extension of collective bargaining agreements.

21 S 28(1)(I).

22 Bezuidenhout et al, supra n 13, 54.

23 S 213 Labour Relations Act 66 of 1995; s 8 Basic Conditions of Employment Act 75 of 1997; s 1 Employment Equity Act 55 of 1998; s 1 Unemployment Insurance Act 4 of 2002.

24 Building Bargaining Council (Southern and Eastern Cape) v Melmons Cabinets 2001 ILJ 120 (LC), Motor Industry Bargaining Council v Mac-Rites Panel Beaters and Spray Painters 2001 ILJ 1077 (N).

25 SA Broadcasting Corporation v Mckenzie 199920 ILJ 585 (LAC).

26 Benjamin, supra n 9, 792.

27 Medical Association of SA v Minister of Health 199718 ILJ 528 (LC). 
The Explanatory Memorandum to the Labour Relations Bill preceding the Labour Relations Act 66 of 1995 noted at par 16.2 that:

The courts' approach is that a contract must be classified on the basis of the 'dominant impression test' gained from examining its terms. This approach has been criticised for offering little guidance in practice to employers and employees. The view has also been expressed that the court's approach involves a formalistic consideration of the differences between a contract of service and a contract for services rather than examining whether it is appropriate that the worker should be protected by labour legislation.

The Commission on the Future of Worker-Management Relations in the USA ${ }^{28}$ proposes a more principled approach:

Workers should be treated as independent contractors if they truly are independent entrepreneurs performing services for clients - i.e., if they present themselves to the general public as an established business presence, have a number of clients, bear the economic risk of loss from their work and the like. Workers who are economically dependant on the entity for whom they perform services generally should be treated as employees. Factors such as low wages, low skill levels and having one or a few employers should all militate against treatment as independent contractors.

Using the above as a guiding principle is more in line with the aim of current labour legislation to protect vulnerable workers against the power of persons or a body acting as the employer. ${ }^{29}$ However, because of the limited reach of South African labour law, it is of the utmost importance for workers to know whether they are employees or independent contractors, and the related uncertainty leaves a large number of workers vulnerable. ${ }^{30}$

Du Toit et al Labour Relations Law 78.

Ibid.

30 Benjamin, supra n 9, 794. 


\subsection{Workers employed by labour brokers (eg Temporary employment services)}

In South Africa employment by a temporary employment service is, to a certain extent, regulated by the LRA and the BCEA. ${ }^{31}$ Section 198(2) provides that the temporary employment service (hereafter TES) is the employer and not the client, and that the person placed is the employee of the TES. According to section 198(3), a person who is an independent contractor is not an employee of a temporary employment service, nor is the temporary employment service the employer of that person. In LAD Brokers (Pty) Ltd v Mandla ${ }^{32}$ the court had to determine whether Mandla was an independent contractor and therefore excluded in terms of section 189(3). The court considered the relationship between Mandla and the client, ${ }^{33}$ and not the relationship between the labour broker and the client. The Labour Appeal Court held that Mandla was an employee of the client and therefore in terms of section 198(2) deemed to be the employee of the labour broker. Item 56 of the "Code of Good Practice: Who is an employee?" provides that in order to determine whether the person supplied to a client by the TES is an employee of the client or an independent contractor, the working relationship between the worker and the client must be considered. ${ }^{34}$ Section 198 of the LRA and section 82 of the BCEA provide that the employment service and client are jointly and severally liable if any standard agreement, legislation, bargaining council agreement, sectoral determination or arbitration award regulating employment conditions is contravened. The client will now, at least, have some legal responsibility for persons employed at their premises. In the Midway Two Engineering \& Construction Services BK $v$ Transnet $B p k^{35}$ the Supreme Court of Appeal even

31 S 198 of the Labour Relations Act 66 of 1995 and s 82 of the Basic Conditions of Employment Act 75 of 1997.

32200122 ILJ 1813 (LAC).

33 In determining the nature of the relationship, the court referred to the dominant impression test and the control test.

34 Item 56 of the code reflects the position in the $L A D$ Brokers case. See Van Niekerk and Christianson Law @work 73.

351999 ILJ 738 (SCA). 
held the client and not the TES vicariously liable for negligence on the part of the employee, as the ultimate control over the employee lay with the client. ${ }^{36}$

Why would an employer use a TES? The stringent labour law requirements are now moved to the TES. In other words, the dismissal procedure must now be complied with by the labour broker and not by the client. The client can use the TES to provide labour when needed - an important factor to consider in respect of labour flexibility. Costs are reduced as it is often less costly to use the services of a person through a TES than to employ a person temporarily. Internationally these workers are often referred to as 'temporary workers'.

\section{Non-standard workers and existing legislation in South Africa}

\subsection{Who is an employee?}

The first challenge that South Africa faces in regulating the protection of nonstandard workers is that the statutory protection provided by labour laws all over the world and in South Africa is based on the common law contract of service. ${ }^{37}$ Apart from excluding members of the Defence Force, the members of the National Intelligence Services and members of the South African Secret Service, ${ }^{38}$ existing labour legislation ${ }^{39}$ in South Africa expressly excludes the independent contractor from the ambit of protection. The question then arises whether or not statutory labour laws should proceed on the foundation of the common law contract of service. ${ }^{40}$ To be identified as an employee in terms of legislation, an individual must either work for another person for remuneration

36 The client may be held liable in terms labour law obligations imposed on categories of persons not restricted to employees. The health and safety obligations of the Occupational Health and Safety Act 85 of 1993 protect not only employees, but also others who are on the premises of the employer.

37 Mills, supra n 3, 1221.

38 S 2 Labour Relations Act 66 of 1995

39 Employment Equity Act 55 of 1998 and the Skills Development Act 97 of 1999 contain essentially the same definition.

40 Mills, supra n 3, 1221. 
or assist another person in any other manner to carry on or conduct that person's business. To assist another would appear to extend the definition beyond common-law employees. ${ }^{41}$ When interpreting the meaning of employee as defined, consideration must be given to section 3 of the LRA. ${ }^{42}$ As far as the interpretation of the LRA in compliance with the Constitution is concerned, this will mean that the Act must be interpreted to ensure the protection, promotion and fulfilment of the labour rights in the Constitution. These Constitutional rights are granted in wide terms, as every person has the right to fair labour practices and every worker has the right to form and join a trade union and participate in the activities and programmes of a trade union, including the right to strike. ${ }^{43}$

Section $213^{44}$ describes an employee as:

(a) any person, excluding an independent contractor, who works for another person or for the State and who receives, or is entitled to receive, any remuneration; and

(b) any other person who in any manner assists in carrying on or conducting the business of an employer, and 'employed' and 'employment' have meanings corresponding to that of 'employee'.

This definition is identical to the definition contained in section 1 of the BCEA. Paragraph (a) refers to the person who works in terms of the common law contract of service and expressly excludes the person who renders service in accordance with the so-called locatio conductio operis, independent contractor. ${ }^{45}$ In paragraph (b) no reference is made to receiving or being entitled to remuneration. At first glance, paragraph (b) can be wide enough to include the independent contractor. The courts have held that persons assisting in the carrying on or conducting of a business are included, but that the

41 Benjamin, supra n 9, 789.

42 To give effect to its primary objects; in compliance with the Constitution and in compliance with the public international law obligations of the Republic.

$43 \mathrm{~S} 23$.

44 Labour Relations Act 66 of 1995

45 SA Broadcasting Corporation v McKenzie 199920 ILJ 585 (LAC) at par 7. 
independent contractor remains excluded. ${ }^{46}$ The wide scope of paragraph (b) is to potentially include workers who do not necessarily have an employment contract. $^{47}$ Section 213 does not differentiate between full-time, part-time, temporary or permanent employees and although they are included in the definition, different levels of protection are afforded to certain categories and the conditions of employment make the enforcement of the rights available to them exceptionally difficult.

As Benjamin ${ }^{48}$ argues, a judge confronted by counsel seeking a wider interpretation of the term employee may reply that counsel is requesting the court to fulfil the role of the legislature, but such a response will miss the issues at hand, and it is suggested that the problem might not lie in the language used but in the manner in which the definition is interpreted. Can we then suggest that a wide interpretation is now eminent to comply with the Constitutional principles to interpret labour law purposively and in accordance with the primary objects of legislation?

\subsubsection{The rebuttable presumption}

Instead of amending the definition of employee or widening the definition, the legislature introduced a rebuttable presumption ${ }^{49}$ in section $200 \mathrm{~A}$ of the LRA and section $83 A$ of the BCEA. ${ }^{50}$ Section $83 A$ states that:

(1) A person who works for, or renders services to, another person is presumed, until the contrary is proved, to be an employee, regardless of the form of the contract, if any one or more of the following factors is present:

46 Borcherds v CW Peace \& F Sheward t/a Lubrite Distributors 199112 ILJ 383 (IC) at 388DE and Niselow $v$ Liberty Life Association of Africa 199819 ILJ 752 (SCA).

47 Du Toit, supra n 28, 67.

48 Benjamin, supra n 9, 804.

49 Part 2 of the Code of Good Practice: Who is an employee, GNR 1774 of 1 December 2006 , deals with the rebuttable presumption as to who is an employee in terms of $s$ 83A of the BCEA and S 200A of the LRA. Any person interpreting these sections must take this Code into account.

50 The wording in these two sections is almost identical. 
(a) The manner in which the person works is subject to the control or direction of another person;

(b) the person's hours of work are subject to the control or direction of another person;

(c) in the case of a person who works for an organisation, the person is a part of that organisation;

(d) the person has worked for that other person for an average of at least 40 hours per month over the last three months;

(e) the person is economically dependent on the other person for whom that person works or renders services;

(f) the person is provided with tools of trade or work equipment by the other person; or

(g) the person only works for or renders services to one person.

(2) Subsection (1) does not apply to any person who earns in excess of the amount determined by the Minister in terms of section 6(3).

(3) If a proposed or existing work arrangement involves persons who earn amounts equal to or below the amounts determined by the Minister in terms of section 6(3), any of the contracting parties may approach the CCMA for an advisory award about whether the persons involved in the arrangement are employees.

A person is presumed to be an employee if the person is able to establish one of the seven factors listed above. Once the presumption is invoked, the onus of proof falls on the employer who must now rebut the presumption on a balance of probabilities. To determine the existence of a contract of employment the courts and arbitrators may once again revert to the common law tests.

Subsection 2 excludes high-income earners and raises the question of whether or not they are immune from exploitation and less deserving of protection than other employees. Jan Theron ${ }^{51}$ states that there can be no valid conceptual rationale for an earnings threshold. Once the factors introduced are valid 
indicators of an employment relationship, they must hold for any employment relationship.

All the presumption has done is to assist employees with problems experienced with the onus of proof, as the employer must now prove why the person who falls within the ambit of one or more of the presumptions is not an employee. Extending the necessary protection to non-standard workers should be a statutory arrangement, as a presumption is not a lasting solution. Certainly the factors mentioned in the presumption must be taken into account when interpreting the definition.

Apart from the forceful approach adopted by the courts, the rebuttable presumption ensures that the employer must produce evidence to support his or her allegations. A person who voluntarily assumes the status of an independent contractor to obtain tax benefits and then tries to reclaim the status of an employee will be dealt with severely by the courts. To discover the true relationship between the parties the courts must not be bound by what the parties chose to call the relationship. ${ }^{52}$ According to the Explanatory Memorandum, ${ }^{53}$ the motivation for the inclusion of the presumption was to assist vulnerable workers and prevent the fraudulent use of independent contractors.

Is it enough to say that the Labour Courts and arbitrators should be entitled to intervene and assist these 'employees'? ${ }^{54}$ Legislative intervention is a better option and it will enable the parties to conduct their affairs with a degree of certainty.

52 SA Broadcasting Corporation v McKenzie 199920 ILJ 585 (LAC) at par 10.

53 Which accompanied the first draft of the 2002 amendments to the LRA and BCEA.

54 Van Niekerk 2005 CLLJ 20. 


\subsubsection{The NEDLAC Code of Good Practice: Who is an employee?}

Section $200 A(4)$ of the LRA states that NEDLAC must prepare and issue a Code of Good Practice that sets out guidelines to determine whether persons are employees. After four years of debating the problems bedevilling the determination of who is an employee, the code was finally adopted during 2006. Items 2(a) and (e) of the Code state the purpose as:

(a) to promote clarity and certainty as to who is an employee for the purposes of the Labour Relations Act and other labour legislation;

(e) to assist persons applying and interpreting labour law to understand and interpret the variety of employment relationships present in the labour market including disguised employment, ambiguous employment relationships, atypical (or non-standard) employment and triangular relationships.

In terms of section 203(3) and (4) of the LRA, any person interpreting or applying the LRA, BCEA, EEA or SDA must take this Code into account for the purpose of determining whether a particular person is an employee.

\subsection{The Basic Conditions of Employment Act 75 of 1997}

The previous BCEA was designed to protect full-time employees only and excluded certain part-time workers from significant benefits. ${ }^{55}$ The Green Paper $^{56}$ proposed a legislative model of 'regulated flexibility' that would balance the protection of minimum standards with the requirements of labour market flexibility. The new act would aim to protect vulnerable employees and employees in non-standard employment and develop appropriate employment standards for employees in the unorganised sector. ${ }^{57}$ The act does not

55 Green Paper on Labour, supra n 1. The Act excluded, eg, temporary employees employed for agricultural and industrial shows. It was suggested that the new Act should cover all employees except members of the security forces and intelligence services, unpaid employees of charitable organisations and trainees, to the extent that their conditions of employment are regulated under other legislation.

56 Green Paper on Labour, supra n 1, 5.

57 Ibid. 
differentiate between casual, temporary or seasonal employees and extends protection to all except employees who work for less than 24 hours a month for an employer. ${ }^{58}$

Certain methods are introduced by the act to extend its protection to the vulnerable worker. In terms of section 50 the Minister may, if it is consistent with the act, make a determination to replace or exclude any basic condition of employment as provided for by the act. This determination may not alter any 'core rights', ${ }^{59}$ but can be made in respect of any category of employees or employers. ${ }^{60}$ Sectoral determinations are used to introduce minimum wage levels rather than to vary basic conditions for those in unorganised sectors and areas where there is very little or no collective bargaining. ${ }^{61}$ Section 57 states that if matters are regulated in this act and in a sectoral determination, the provision in the sectoral determination will prevail. It is clear from the number of sectoral determinations that the Minister is not hesitant to use this powerful tool to extend protection to those in need. ${ }^{62} \mathrm{~A}$ number of sectoral determinations have been used effectively to provide protection to non-standard workers. The sectoral determination for the retail sector provides part-time workers with an option to receive benefits, for example with regard to leave, similar to those of full-time employees. ${ }^{63}$ The success of sectoral determinations depends on the enforcement of such determinations. The previous act provided for enforcement through the criminal justice system. The new BCEA provides for an enforcement system that is essentially based on voluntary compliance administered by the inspectorate of the Department of Labour as a measure of first resort, and eventually compulsory compliance as a last resort, should the voluntary

58 S 6(1)(c) of the Basic Conditions of Employment Act 75 of 1997.

59 Ss $7 ; 13 ; 17(3)$ and (4); 25; 43(2); 44 and 48 or a regulation made in terms of s 13, for core rights protected by the Basic Conditions of Employment Act 75 of 1997.

$60 \mathrm{~S} 50(1)(\mathrm{a})$.

61 Ss 51 and 55.

62 Examples of sectoral determinations that have been issued include the Contract Cleaning sector (1999); Civil Engineering Sector (1999); Private Security Sector (2001); Clothing and Knitting (2000); Learnership (2001); Domestic Workers (2002); Farm Workers (2002), Wholesale and Retail Sector (2002), Taxi Sector (2005) and the Forestry Sector (2006). Benjamin 2008 ILJ 1593. 
approach fail. ${ }^{64}$ Enforcement of rights must be supported by an effective system of labour inspection and speedy access to the judicial system. The act promotes an amicable rather than a punitive approach in an attempt to improve on the failings of the previous system. ${ }^{65}$

In terms of section 83, the Minister may, on advice of the Employment Conditions Commission and by notice in the Government Gazette, deem any category of persons specified in the notice to be employees for the purposes of the whole or any part of the BCEA or any other employment law or sectoral determination. Section 83 certainly indicates the importance attached to the extension of protection to vulnerable and non-standard workers. This means that once non-standard workers are pronounced employees by the Minister they are free to join unions. This would enable them to become part of the distributional framework of the LRA.

However, it can be asked why the act does not regulate the position of nonstandard workers directly, and whether or not it is wise to leave a matter of such importance up to the discretion of the Minister to adopt measures when he/she deems it appropriate. ${ }^{66}$ It certainly does not deal with the necessary protection from a principled perspective. ${ }^{67}$ Given the growth in non-standard work, why has the Minister not used this power more extensively? A reason might be that there is reluctance to use an administrative authorisation to address such a difficult problem. Procedures could be incorporated within the act for unions, workers and NGOs to notify the Minister of the employment status of certain workers, in order to make him/her aware of categories of vulnerable workers and to enable him/her to use his/her powers in terms of the

64 See ch 10 of the Act.

65 Du Toit, supra n 28, 528.

66 Olivier 1998 ILJ 2199.

67 Ibid. 
act. $^{68}$ A more principled approach, offering specific legislative protection, would be preferable to this discretionary one.

\subsection{The South African Constitution}

The Constitution casts its net of protection widely, as is evident from the wording used in section 23, which grants all workers the right to fair labour practices - the right to strike, form and join a union, participate in their activities and programmes, and bargain collectively. ${ }^{69}$ The entrenchment of these rights in the Constitution is a clear recognition of their significance to South African workers. $^{70}$

In the SA National Defence Union case ${ }^{71}$ the question arose as to whether or not members of the armed forces, who are expressly excluded from labour legislation, were 'workers' as contemplated by section 23(2) of the Constitution, for the purposes of the right to join a trade union. The court stated that the wording of section 23 refers to those who are working for an employer and who have entered into a contract of employment to provide services to an employer. ${ }^{72}$ Although members of the Defence Force did not have contracts of employment, the court found that their conditions of enrolment in the Defence Force were akin to the conditions of persons employed under contracts of employment and therefore concluded that they were workers. ${ }^{73}$ Conventions and recommendations of the ILO were relied on to assist the court in considering the meaning and scope of the word 'worker' used in section $23 .^{74}$ According to the ILO, members of armed forces are workers but their position is considered as special, leaving it to member states to determine to what extent

68 Ibid.

69 Likewise employers enjoy the constitutional protection as s 23(3) grants every employer the right to form and join an employers' organisation and to participate in the activities and programmes of an employers' organisation

70 South African National Defence Union v Minister of Defence 19994 SA 469 (CC) par 20.

7119994 SA 469 (CC)

72 South African National Defence Union v Minister of Defence 19994 SA 469 (CC) par 22.

73 Ibid, par 23, 24 and 27.

74 Art 2 and 9 of the ILO Freedom of Association and Protection of the Right to Organise Convention 87 of 1995. 
the relevant conventions should apply. The court stated that the interpretation of rights should be generous and should accord to individuals the full protection of these rights. ${ }^{75}$

What does this judgment mean for the non-standard worker? It is clear from the above case that at least some non-standard workers who do not satisfy the definition of an 'employee' contained in relevant labour laws might find protection under the Constitution. These workers would include workers with a relationship akin to an employment relationship.

Section 23(1) of the Constitution grants everyone the right to fair labour practices and there are several indications that the scope of the constitutional right to fair labour practices is wider than the concept of unfair labour practices in the LRA. ${ }^{76}$ For example, in the Mondi Kraft case ${ }^{77}$ the court commented that the right to fair labour practices enshrined in the Constitution protects both the employer and employee. Consideration should be given to section 23(1) which provides protection to non-standard workers who do not fit the definition of employee as provided for in the LRA, since section 23(1) grants the right to everyone.

Though the International Covenant on Economic, Social, and Cultural Rights, which South Africa has still not ratified, and the African Charter on Human and People's Rights, which South Africa has ratified, contain the right to work, the South African Constitution does not contain such a right. ${ }^{78}$

\subsubsection{Discrimination and the Constitution}

The important role of equality and human dignity as founding values is evident throughout the Constitution and constitutional judgments.

75 South African National Defence Union v Minister of Defence 19994 SA 469 (CC) par 28.

76 Slabbert et al Managing Employment Relations 5.

77 Mans v Mondi Kraft 2000 ILJ 213 (LC).

78 Art 6 of the International Covenant on Economic, Social and Cultural Rights 1966; art 15 of the African Charter of Human and People's Rights, 1981. 
Section 9 contains the equality provision, declaring everyone equal before the law and guaranteeing everyone the right to equal protection and benefit of the law. Section 9(4) prohibits direct and indirect discrimination. Direct discrimination occurs when the reason for discrimination is explicit and indirect discrimination takes place when the use of seemingly neutral criteria has a disproportionately adverse impact on a particular group. The list of prohibited grounds is potentially unlimited, including race, gender, ethnic or social origin, colour, age, disability, religion, culture, language and birth. In the case of discrimination on a listed ground, the burden of proof that the discrimination is fair is placed on the person who infringed the right to equality. Discrimination is presumed unfair unless it is established that the discrimination is fair. ${ }^{79}$ As fundamental rights are not absolute and are subject to limitations of a reasonable nature, section 9 is subject to the general limitation clause in section 36 of the Constitution. This means that once the discrimination is proved unfair, it will be unconstitutional only if it cannot be justified in terms of section 36 .

In certain sectors non-standard workers are predominantly female, black and unskilled, ${ }^{80}$ and by excluding them, a certain group of people is negatively affected. Non-standard workers excluded by the definition of employee as contained in the LRA, the BCEA and the EEA can rely on the constitutional protection.

\subsection{The Employment Equity Act 55 of 1998 and the Promotion of Equality and Prevention of Unfair Discrimination Act 4 of 2000} In the Employment Equity Act 55 of 1998 (hereafter EEA), the prohibition of unfair discrimination is similar to that in the Constitution, except that the EEA includes family responsibility, political opinion and HIV status as listed

$79 S 9(5)$.

$80 \mathrm{Eg}$, homeworkers in the retail sector. 
grounds. ${ }^{81}$ The listed grounds are not limited as the wording of the section uses the word 'including' before the listed grounds are stated. The EEA applies to all employers and employees ${ }^{82}$ except members of the National Defence Force, the National Intelligence Agency, the South African Secret Service and the South African National Academy of Intelligence. ${ }^{83}$ Two justification grounds are provided for in section 6(2) (a) and (b). ${ }^{84}$ Non-standard workers who are included in the EEA's definition of employee can make use of the protection granted by section 6 of this act in terms of either direct or indirect discrimination.

Non-standard workers excluded by the definition of employee in the EEA can seek protection under the scope of the Promotion of Equality and Prevention of Unfair Discrimination Act 4 of 2000 (hereafter PEPUDA). ${ }^{85}$ This act is not intended to overlap or displace the EEA, as it applies to the workplace in respect of matters that do not fall within the ambit of the EEA, nor does the Act apply to any person to whom the EEA applies. ${ }^{86}$ Section 1 defines discrimination as any act or omission, including a policy or law, rule, practice, condition or situation, which directly or indirectly imposes burdens, obligations or a disadvantage on, or withholds benefits, opportunities or advantages from, any person on one or more prohibited grounds. ${ }^{87}$ Section 6 of this act provides that neither the State nor any other person may unfairly discriminate against any person.

Non-standard workers, excluded from the scope of the EEA, could find protection in terms of this act, for example under section 7 , which prohibits unfair discrimination on grounds of race, and/or in terms of section 8 , which

81 S 6 Employment Equity Act 55 of 1998.

82 In terms of $\mathrm{s} 9$ an employee includes an applicant for employment.

$83 \mathrm{~S} 4$

84 Affirmative action measures and inherent job requirements.

85 The Constitution enjoined Parliament to enact legislation to prevent unfair discrimination. See s 9(3) read with item 23 (1) of sch 6.

86 Strydom et al Essential Employment Discrimination Law 287. See s 5(3) of the Act.

87 Prohibited grounds are defined in s 1 and include race, gender, sex, pregnancy, ethnic or social origin, colour, sexual orientation, age, disability, religion and culture. 
prohibits unfair discrimination on the grounds of gender, as women have historically always comprised the majority of non-standard workers and sectors characterised as vulnerable often comprise black, unskilled workers. ${ }^{88}$

\subsection{Lessons to be learnt from the European Court of Justice (ECJ) and the prohibition on discrimination}

The use of the prohibition on possible discrimination to provide protection to vulnerable workers in the European Union can provide valuable assistance for the possible adoption of similar approaches in South Africa specifically for parttime workers. Though the Council Directive 97/81/EC in relation to the Framework Agreement on Part-Time Work ${ }^{89}$ was a welcome attempt to protect part-time workers, it can be argued that the above court has ensured the protection of these workers on the basis of a prohibition of discrimination long before the inception of the above directive.

The case law in respect of part-time workers was initiated from the perspective of alleged discrimination with reference to pay. The Jenkins $v$ Kingsgate (Clothing Productions) $L t d^{90}$ case was significant as it was the first decision of the European Court of Justice (ECJ) where the concept indirect discrimination was extended to equal pay claims in terms of article $119 .{ }^{91}$ The court stated that a difference in pay between part-time workers and full-time workers could amount to discrimination in terms of article 119 except if the employer could objectively justify the difference. The court held that paying Ms Jenkins less than her full-time male colleagues would be justified in terms of article 119 only if it were "attributable to factors which are objectively justified and are in no way related to any discrimination based on sex". ${ }^{92}$

88 Mills, supra n 3, 1209.

89 See par 4.2.

90 [1981] 2 CMLR 24. Art 119 of the EEC Treaty has been renumbered as 141 under the new Treaty of Amsterdam.

91 Equal Pay Directive 75/117/EEC.

92 Jenkins v Kingsgate (Clothing Productions) [1981] 2 CMLR 24. Dupper 2002 SA Merc LJ 232. An example of justification will be where an employer encourages full-time work on economic grounds that may be objectively justified. 
In the Bilka-Kaufhaus case ${ }^{93}$ ECJ held that though Bilka made no distinction in respect of the hourly pay of the workers, he granted occupational schemes only to full-time workers. The court found that occupational schemes fell within the definition of pay as contained in article 119 and that article 119 was infringed by the exclusion of part-time workers from its occupational pension scheme, where that exclusion affects a far greater number of women than men, unless the undertaking showed that the exclusion is based on objectively justified factors unrelated to any discrimination of sex. ${ }^{94}$

In these cases the Court of Justice utilised a four-step enquiry to decide on the alleged discrimination. The first step entailed a scrutiny of whether either a member state's law or collective agreement contained a provision within the scope of the following directives, namely, the non-discrimination rule in article 141 Directive 75/117/EEC referring to equal pay, Directive 86/378/EEC ${ }^{95}$ in respect of occupational pension schemes, Directive 76/207/EEC on equal treatment with regard to working conditions, the Directive ${ }^{96}$ on the prohibition of discrimination in statutory social security schemes, the Directive ${ }^{97}$ on the safety and health at work of pregnant woman, and the Directive ${ }^{98}$ concerning the organisation of work time. ${ }^{99}$

The court will then proceed to investigate if any difference of treatment between part-time workers and full-time workers exists. The question is then whether the different treatment impinges on significantly more female workers than male workers. This becomes an extremely important scrutiny in cases of indirect discrimination and the court will rely on available statistics. The last question is

93 Bilka-Kaufhaus GmbH v Weber von Hartz [1986] 2 CMLR 701.

94 See par 31 of this judgment.

95 The directive on implementation of equal treatment for men and woman in occupational social security schemes.

96 Directive 79/7/EEC.

97 Directive 92/85/EEC.

98 Directive 93/104/EEC.

99 Traversa "Protection of part-time workers" 410. 
then whether the difference in treatment can be justified by objective factors not related to sex.

It seems that our courts are hesitant to find in favour of an applicant alleging unfair discriminatory wage policies. ${ }^{100}$ This can be ascribed to the difficulty in determining a rational basis for differentials. Determining permissible criteria can also prove problematic. Race, sex and age cannot alone justify differentiation and the court in these cases would consider factors like qualifications, skills efficiency, seniority and responsibility. ${ }^{101}$ Part-time workers in South Africa should be able to rely on the principal of equal pay for equal work, until specifically tailor-made legislation is introduced, as their counterparts in the European Union were able to do, though our courts seem more reluctant to entertain these claims than the European Court of Justice. Courts need to be less deferential to the reasons that employers offer for the differential treatment between full-time workers and part-time workers. The courts need to cautiously balance the interest of the parties always keeping in mind our constitutional commitment to equality.

It is clear from the above discussion that the concept of 'indirect discrimination' can be an important tool used to provide labour and social security protection to non-standard workers.

\section{$4 \quad$ International law}

The Constitution encourages an international and foreign law-friendly approach. ${ }^{102}$ The Constitutional Court has confirmed that conventions and

100 Transport and General Workers Union v Bayette Security Holdings 1999 ILJ 1173 (LC); NUMSA v Gabriels Case 523/2001 (LC) 2 December 2002 (unreported); Louw v Golden Arrow 2000 ILJ 188 (LC), and Mahlangu v Amplats Development Centre 2002 ILJ 910 (LC).

101 Grogan Workplace Law 303.

102 S 39(1)(b) and (c) and s 233. 
recommendations are a major source of South Africa's public international law obligations. $^{103}$ Section 39(1) (c) states that a court, tribunal or forum may consider foreign law when interpreting the Bill of Rights. Section 39(1) (b) requires that these bodies must consider international law even though they are not bound to follow it. ${ }^{104}$ Section 233 states that when interpreting any legislation, every court must prefer any reasonable interpretation of the legislation that is consistent with international law over any alternative interpretation that is inconsistent with international law.

\subsection{The International Labour Organisation and new forms of work}

New forms of work have been recognised by the International Labour Organisation (hereafter ILO) and in terms of its standard setting it covers employees outside the traditional employment relationship.

During the last century, the ILO has played a very important role in developing labour standards and conventions. The changes in the traditional concept of work have not escaped the attention of the ILO, which has acknowledged the increase in the need for labour and social protection of non-standard work in the following ways: ${ }^{105}$

(a) Conventions and recommendations pertaining to particular categories of non-standard workers, such as part-time workers and homeworkers.

(b) Support for micro-enterprises in the informal economy.

(c) Programmes like Strategies and Tools against Social Exclusion and Poverty (STEP) to promote the extension of social protection to informal workers.

(d) Support for mutual health insurance schemes.

(e) The continuance of work at its Social Security Department, commissioning research and investigating the extension of social security protection to non-standard workers.

103 In S v Makwanyane 19953 SA 391 (CC) the court stated that public international law includes binding and non-binding law.

104 Olivier, Smit and Kalula Social Security 59.

105 Lund and Srinivas 2000 Learning from experiences 26. 
The ILO has also adopted the concept of decent work and has set four pillars of decent work for all, namely employment opportunities, workers' rights, social protection, and representation. This concept of decent work should have an impact on the improvement of the precarious position of non-standard workers. Most core labour standards ${ }^{106}$ apply to all workers or contain provision for extension to other categories of workers. Furthermore, the ILO has adopted the Declaration on Fundamental Principles and Rights at Work of 1998. In terms of this declaration, member states are required to adopt at least the core conventions containing certain core rights.

During 2006 the ILO adopted the Employment Relations Recommendation. The Recommendation provides guidelines to member states in determining whether or not an employment relationship exists in situations where the respective rights and obligations of the parties are not clear. In terms of article 1, member states should formulate and apply a national policy for reviewing, clarifying and adapting the scope of their relevant labour law to provide effective protection for workers. The Recommendation provides that national policy should be designed and implemented in consultation with representative organisations. This policy should include guidelines for employers and workers to effectively establish the existence of the employment relationship, combat disguised employment relationships, and ensure protection to vulnerable workers $^{107}$ affected by the uncertainty as to the existence of an employment relationship. ${ }^{108}$ Article 9 provides that to determine the existence of an employment relationship one should be guided by the facts relating to the performance of work and the remuneration of the worker, and not by how the relationship is characterised in contractual arrangement between the parties.

106 Core rights include freedom of association, the right to collective bargaining, the elimination of forced labour, the elimination of discrimination and the abolition of child labour.

107 Including women, young workers, older workers, workers in the informal economy, migrant workers and workers with disabilities.

108 Art 4(a), (b) and art 5 of Employment Relations Recommendation 2006. 
When facilitating the determination of the existence of an employment relationship, member states should provide for a legal presumption that an employment relationship exists, where one or more relevant indicators are present. $^{109}$ Member states should include in their national laws specific indicators of the existence of an employment relationship. ${ }^{110}$ Relevant indicators include the fact that the work is carried out according to the instructions and under the control of another party, involves the integration of the worker in the organisation, is performed solely for the benefit of another person, and must be carried out personally by the worker. The indicators referred to in the Recommendation 2006 reflect the tests ${ }^{111}$ developed by civil courts in England and in South Africa. ${ }^{112}$

The Recommendation covers the establishment of an appropriate mechanism or the use of an existing one for monitoring developments in the labour market to formulate, apply and review relevant laws.

The Recommendation does not extend guidelines to the triangular employment relationship. The Homework Convention ${ }^{113}$ and the Convention adopted on Private Employment agencies in 1997 are the only international instruments pertaining to the triangular employment relationship. ${ }^{114}$

\subsubsection{The Part-Time Work Convention 175 of $1994^{115}$}

The Part-Time Work Convention was adopted in 1994 and to date has been ratified by 11 countries. ${ }^{116}$ This convention not only promotes part-time work but also provides for the extension of protection for these workers.

109 This presumption exists in South African labour legislation. See s 200A of the LRA and s 83A of the BCEA.

110 Art 13 (a) and (b).

111 See the control test and organisation test.

112 Grogan, supra n 101, 19.

113 Supra n 18.

114 Theron, supra n 51, 1.

115 See the Recommendation of Part-Time Work 182 of 1994. 
The convention recognises the economic importance of part-time work, as well as the need for employment policies to consider the role of part-time work in facilitating additional employment opportunities and to ensure protection for these workers in the areas of access to employment, working conditions and social security.

This convention provides that measures must be taken to ensure that part-time workers receive the same protection as that accorded to full-time workers in respect of the right to organise, the right to bargain collectively, occupational safety and health, and discrimination in employment and occupation. ${ }^{117}$

Article 5 provides that part-time workers should not, solely because they work part-time, receive a basic wage calculated "proportionately on an hourly, performance-related or piece rate basis" that is lower than the basic wage for full-time workers calculated in the same way.

Article 7 provides for the same maternity protection, paid annual leave and paid public holidays and sick leave as those of comparable full-time workers. The promotion of part-time work is regulated by article 9 . In terms hereof measures must be taken to facilitate access to productive and freely chosen part-time work that meets the needs of both employers and workers. These measures include the review of laws and regulations that may prevent or discourage recourse to acceptance of part-time work and the use of employment services where they exist.

Countries that have ratified the convention must identify and publicise possibilities for part-time work in their information and placement activities, and

116 Albania, Cyprus, Finland, Guyana, Italy, Luxembourg, Mauritius, Netherlands, Slovenia, Portugal and Sweden have ratified this Convention. ILOLEX www.ilo.org/ilolex. [4 August 2008].

117 Art 4. 
perform research and disseminate of information on the degree to which parttime work responds to the economic and social aims of employers and workers.

\subsubsection{Homework Convention 177 of 1996}

This Convention was adopted two years later and recognised that there are workers who do not work at the place of the employer but are in need of protection. ${ }^{118}$ The convention extends protection to homeworkers and endeavours to supplement the conventions and recommendation applicable to homeworkers by standards that take into account the special characteristics of homework. This convention has been ratified by only five countries, ${ }^{119}$ and there seem to be few countries where homework is predominant.

The Convention recognises the need to protect workers that are supposedly self-employed and to render such protection. It identifies and holds the 'employer' liable based on an identifiable economic relationship rather than on a contract of employment.

Ratification of this convention would compel governments to adopt policies to promote equality of treatment between homeworkers and wage earners by taking into account the specific characteristics displayed by homeworkers. ${ }^{120}$ Equality of treatment must be promoted in relation to these workers' right to establish or join an organisation of their choice, and to participate in its activities; to protection against discrimination in employment and occupation; to protection in the field of occupational health and safety, and to remuneration. Statutory social protection, maternity protection and access to training is to be provided. ${ }^{121}$ A national policy on homework must be implemented through laws

118 Bezuidenhout et al, supra n 13, 1.

119 Albania, Argentina, Finland, Ireland and Netherlands. ILOLEX http://www.ilo.org/ilolex 4 Aug. 
and regulations, collective agreements, arbitration awards, or in another appropriate manner. ${ }^{122}$

\subsubsection{The Maternity Protection Convention 183 of 2000}

This convention applies to all 'employed women' including those in atypical forms of dependent work, and it has been ratified by 16 countries. ${ }^{123}$

The convention recognises the circumstances of women workers and the need to provide protection for pregnant workers, and avers that this is a shared responsibility of government and society. The convention recognises and seeks to protect female workers in the informal economy, as the definition of 'woman' includes "any female person without discrimination whatsoever". Article 2 extends the protection to women in atypical forms of dependent work. This convention can certainly be a powerful tool in the protection of female workers in atypical forms of dependent work but, unfortunately, ratification of this convention remains rare. Should South Africa ratify this convention, the BCEA would have to extend its protection to those female workers who are presently excluded.

\subsubsection{Workers with Family Responsibility Convention 156 of 1981}

This Convention recognises that the problems of all workers with family responsibilities are aspects of wider familial and societal issues, which should be taken into account in national policies. Apart from acknowledging the needs of workers with family responsibilities, measures compatible with national conditions should be implemented to develop or promote community services such as child-care. All branches of economic activity and all categories of workers are covered by this convention and it has been ratified by 40 countries. $^{124}$ 


\subsubsection{Freedom of Association and the Right to Organise Convention 87 of 1948}

The ILO's core instrument, Convention 87 of 1948, has been ratified by 149 countries $^{125}$ and has a wide scope.

The Freedom of Association Committee of the governing body of the ILO has held that criteria for determining persons covered by this convention are not based on the existence of an employment relationship and should include agricultural workers and the self-employed. ${ }^{126}$ The committee further extends the application of this convention to all workers, whether they are employed on a permanent or fixed-term basis, or as contract employees.

South Africa has ratified this convention ${ }^{127}$ and its wide scope of coverage, extending the right to establish and join organisations to all workers and employers without any distinction whatsoever might indicate that the LRA, in granting only every 'employee' the right to join a trade union and participate in its activities, is not in line with the wider interpretation of 'worker' to be found in this convention. ${ }^{128}$

Article 2 states that workers and employers without distinction shall have the right to establish and, subject only to the rules of the organisation concerned, join organisations of their own choosing, without prior authorisation.

\subsubsection{The Rural Workers' Organisation Convention 141 of 1975}

This convention recognises that there is a massive under-utilisation of land and labour particularly in developing countries, and that this makes it imperative to encourage rural workers to develop free and viable organisations capable of

$125 \mathrm{Ibid}$.

126 Freedom of Association, supra n 74, 235-236.

127 The provisions of the Convention are thus binding international law. 128 S 4. 
protecting the interests of their members and ensuring their effective contribution to economic and social development. Convention 141 of 1975 has been ratified by 40 countries. $^{129}$

This convention applies to all types of organisations of rural workers, including organisations not restricted to but representative of rural workers. ${ }^{130}$ A rural worker is defined as any person engaged in agriculture, handicrafts or a related occupation in a rural area, whether as a wage earner or a self-employed person such as a sharecropper or a small owner-occupier who derives his/her main income from agriculture, who works the land him/herself, with the help of the person's family or with occasional outside labour. ${ }^{131}$

Article 5 provides that countries that ratify this convention shall adopt and carry out a policy of active encouragement of these organisations with a view to eliminating obstacles, including such legislative and administrative discrimination against rural organisations and their members as may exist.

\subsection{Comparative experiences: Non-standard workers and the European Union}

As non-standard work has become more common throughout the world, the European Commission consulted the European social partners in 1995 on a framework for legislative protection. This resulted in the European Framework Agreement on Part-Time Work. ${ }^{132}$ This agreement displays willingness on the part of social partners to establish a general framework for the elimination of discrimination against part-time workers and to assist with the development of opportunities for these workers.

129 See ILOLEX http://www.ilo.org/ilolex 4 Aug. South Africa has not ratified this convention.

130 Art 1.

131 Art 2.

132 Directive 97/81/EC. 
The Framework Agreement on Part-Time Work applies to all part-time workers who have an employment contract or employment relationship as defined by law, a collective agreement or practice in force in each member state. ${ }^{133}$ Apart form prohibiting discrimination the Framework Agreement promotes part-time work, as member states must remove obstacles of a legal or administrative nature which limit opportunities for part-time workers. ${ }^{134}$

The 1997 Equal Treatment for Part-Time Workers Directive encourages social partners to remove obstacles that limit opportunities for the expansion of parttime work, and to give part-time workers equal hourly pay, pro-rata entitlements to sick leave and maternity pay, equal treatment for holidays, maternity leave, parental leave, and career breaks, redundancy, pension schemes and training. This directive has two objectives: one is the removal of discrimination, and the other is the development of part-time work on a voluntary basis.

Self-employed persons enjoy the protection of several directives, including the treaty establishing the European Community. Article 47 of this treaty provides that the Council shall issue directives for the mutual recognition of diplomas, certificates and other formal qualifications of self-employed persons to enable them to pursue activities as self-employed persons. ${ }^{135}$ The European Court of Justice reinforced the treaty's provisions by defining 'workers' as all persons engaged in economic activity. ${ }^{136}$ Thus, the provisions covering the free movement of workers also apply to the self-employed. The purpose of the directive on the application of equal treatment between men and women engaged in a self-employed capacity is to ensure the principle of equal treatment between men and women who are self-employed. ${ }^{137}$ Article 4 provides protection to workers during pregnancy and motherhood and extends

$133 \mathrm{Cl} 2$.

$134 \mathrm{Cl} 4$ and 5.

135 Directive 89/48/EEC of 21 December 1988 on a general system for the recognition of higher education diplomas awarded on completion of professional education and training of at least the last three years' duration.

136 "Self-employed person". See EURLex http://eur-lex.europa.eu/en/index.htm 2 Aug.

137 Directive 86/613/EEC. 
this protection to the wives of the self-employed. ${ }^{138}$ Though protection is provided by different instruments, it appears that the self-employed enjoy more protection in the European Community than do some other categories of nonstandard workers.

Certain seasonal workers could benefit from the directive on an employer's obligation to inform employees on the conditions applicable to the contract or their employment relationship. ${ }^{139}$ This directive extends protection to workers by obliging employers to inform workers of the conditions applicable to their working relationship. However, article 1(2)(b) provides that member states may provide that this directive shall not apply to employees with a contract or employment relationship with a total duration not exceeding one month and/or with a working week not exceeding eight hours. Seasonal workers employed on short-term contracts can thus be excluded. ${ }^{140}$ This directive also applies to casual workers unless its non-application is justified. The coverage of this directive is dependant not on classification but on justification and excludes the possibility that parties themselves can exclude the relationship from the scope of this directive ${ }^{141}$. Non-application of this directive can be justified if other means are adopted to ensure that casual workers are informed of the conditions applicable to their contract. Seasonal workers who work regularly on fixed-term contracts during the season qualify for protection under the Framework Agreement on Fixed-Term Work. ${ }^{142}$

138 Art 2 extends protection to the spouses of these workers where they habitually participate in the activities of the self-employed worker and perform ancillary tasks.

139 Directive 91/533/EEC.

140 Art 1(2)(b). However, it would necessary to establish objective reasons for excluding seasonal workers from the scope of this Directive.

141 Bilka-Kaufhaus GmbH v Karin Weber von Hartz Case 170/84 ECR. The court developed a definition of "objective justification" that can apply in indirect sex discrimination cases. The court stated: "the means chosen for achieving that objective correspond to a real need on the part of the undertaking, are appropriate with a view to achieving the objective in question and are necessary to that end".

142 Directive 97/81/EC. 
It is clear that European Union Member States were not unaffected by the problems associated with non-standard workers. Directives issued by the European Union are binding in nature and Members States must comply with these directives. Thus, the regulation of non-standard workers in the European Union appears to be more effective than the regulation of non-standard workers by the ILO.

\section{$5 \quad$ Conclusions}

It is clear that the nature of work has changed and that this is a universal phenomenon. The increase of competition and different patterns of demand for goods and services have displaced the contract of employment on which our labour legislation is based. ${ }^{143} \mathrm{~A}$ broader interpretation of the statutory definition of an employee to bring it in line with the Constitution and the primary objects of legislation is essential.

Can existing definitions be reconciled with the new concept of employee? Perhaps the time has come to revisit the definition of employee ${ }^{144}$ and introduce an appropriate definition of employer.

The LRA and the BCEA, though committed to social justice, labour peace and democratising of the workplace, ${ }^{145}$ are struggling to cope with the emerging non-traditional forms of employment. An attempt has certainly been made by the new BCEA to extend a minimum floor of rights to those in a precarious position. ${ }^{146}$ Unfortunately, the way chosen to extend coverage does not provide for the involvement of those affected. Labour legislation provides, for example,

143 Van Niekerk, supra n 54, 20.

144 Ibid.

$145 \mathrm{~S} 1$ of the LRA and s 2 of the BCEA.

146 The Act does not differentiate between casual, temporary or seasonal employees and extends protection to all except employees who work for less than 24 hours a month for an employer. 
dismissal protection to non-standard workers covered by the statutory definition of 'employee'. Non-standard workers who do not fall within the scope of 'employee' as defined in the LRA and BCEA are not covered by the protective measures provided by the acts. Special protective measures must be taken to provide protection to these non-standard workers ${ }^{147}$ and the enforcement of existing measures must be improved.

During the apartheid era the South African labour market was characterised by racial discrimination and inequalities. Has the post-apartheid era brought into existence new forms of exclusion that limit the ability of legislation and unions to redress the legacy of the racial and gender discrimination of the past? ${ }^{148}$ On the one hand, the new labour market structures endeavour to bring about redress, advanced economic development, social justice, labour peace and democratisation of the workplace, and to achieve equality in the workplace, ${ }^{149}$ but on the other, casualisation, externalisation and infomalisation limit the impact thereof. Is there a way out of this labour market stalemate ${ }^{150}$

It is clear that the ILO has been concerned about vulnerable workers in nonstandard employment. The ILO extends coverage to non-standard workers through specific conventions for the general acceptance, promotion and extension of protection to these workers. Some of the core conventions ${ }^{151}$ of the ILO extend protection to non-standard workers, and this wide coverage of workers is in line with the ILO's mandate to protect all workers. ${ }^{152}$ Internationally the trend is to extend coverage to include non-standard workers but the number of countries that have ratified some of these Conventions remains low, and thus the effectiveness of these Conventions in protecting the position of non-standard workers is limited. We can therefore only urge the ILO to

147 Olivier 1998 ILJ 684.

148 Webster and Bezuidenhout 2005 http://www.sarpn.org.za/ 27 Nov, ch 5 at 28.

149 See $s 1$ of the LRA and s 2 of the EEA.

150 Webster, supra n 148, 28.

151 Freedom of Association, supra n 74, ratified by South Africa, and the Maternity Protection Convention 183 of 2000 , which applies to all employed women.

152 Benjamin, supra n 63, 1581. 
campaign for ratification related to the protection of non-standard workers. Conventions that have been ratified can be effective only if the provisions are reflected in the national legislation and policies of the ratifying countries. ${ }^{153}$

Taking a closer look at the profile of the non-standard worker in South Africa, we find that the majority of them are those previously disadvantaged by the apartheid regime, comprising women and black, unskilled workers. The exclusion of these workers from labour and social protection can be seen as a form of the discrimination prohibited by almost all labour legislation in South Africa. ${ }^{154}$ Bearing in mind the commitment of the Constitution to equality, human dignity and reconciliation, it is essential that solutions be found to assist the non-standard worker.

153 The ILO Employment Relations Recommendation 2006 recommends the promulgation of national policy to provide guidance.

154 Women and black unskilled workers. 


\section{Bibliography}

Benjamin 2004 ILJ

Benjamin P "An accident of history: Who is (and who should be) an employee under South African labour law?" 2004 Industrial Law Journal 788-804

Benjamin 2008 ILJ

Benjamin P "Informal work and labour rights in South Africa" 2008 Industrial Law Journal 1579-1604

Bezuidenhout et al "Non-standard employment"

Bezuidenhout A, Godfrey S and Theron J with Modisha M "Non-standard employment and its policy implications" Report submitted to the Department of Labour (Sociology of Work Unit, University of the Witwatersrand and Labour and Enterprise Project, University of Cape Town 2003)

Du Toit et al Labour Relations Law

Du Toit D et al Labour Relations Law: A comprehensive guide $5^{\text {th }}$ ed (LexisNexis Butterworths 2006)

Dupper 2002 SA Merc LJ

Dupper O "Part-time employees and the pursuit of substantive equality: A comparative study of the potential and limitations of discrimination law" 2002 South African Mercantile Law Journal 221-252

Godfrey et al 2005 "On the outskirts"

Godfrey S, Clarke M and Theron J with Greenburg J "On the outskirts but still in fashion: Homeworking in the South African clothing industry" Development and Labour Monograph Series (UCT Institute of Development and Labour Law Cape Town 2005)

Grogan Workplace Law

Grogan J Workplace Law (Juta Kenwyn 2007) 
Lund and Srinivas 2000 Learning from experiences

Lund F and Srinivas S Learning from experiences: A gendered approach to social protection for workers in the informal economy (International Labour Office Geneva 2000)

Mills 2004 ILJ

Mills SW "The situation of the elusive independent contractor and other forms of atypical employment in South Africa: Balancing equity and flexibility" 2004 Industrial Law Journal 1203-1235

Olivier 1998 ILJ

Olivier M "Extending labour law and social security protection: The predicament of the atypically employed" 1998 Industrial Law Journal 669686

Olivier Impact of the Constitution

Olivier MP "Impact of the Constitution on labour law and employment relations" in "Statutory Employment Relations in South Africa" in J Slabbert et al (eds) Managing employment relations in South Africa (LexisNexis Butterworths Durban 2005)

Olivier The contract of employment

Olivier MP "The contract of employment" in "Statutory Employment Relations in South Africa" in Slabbert J et al Managing employment relations in South Africa (LexisNexis Butterworths Durban 2005)

Olivier, Smit and Kalula Social Security

Olivier MP, Smit N and Kalula ER (eds) Social Security: A legal analysis

(LexisNexis Butterworths Durban 2003)

Slabbert et al Managing employment relations

Slabbert J et al (eds) Managing employment relations in South Africa (LexisNexis Butterworths Durban 2005) 
Strydom Essential Employment Discrimination

Strydom EML et al Essential Employment Discrimination Law (Juta

Lansdowne 2004)

Theron 2008 ILJ

Theron J "The Shift to services and triangular employment: Implications for labour market reform" 2008 Industrial Law Journal 1-21

Theron 2003 ILJ

Theron J "Employment is not what it used to be" 2003 Industrial Law

Journal 1247-1282

Thompson 2003 ILJ

Thompson C "The changing nature of employment" 2003 Industrial Law Journal 1793-1815

Traversa "Protection of part-time workers"

Traversa $E$ "Protection of part-time workers in the case law of the Court of Justice of the European Communities" in Blanpain R and Weiss M (eds) Changing industrial relations and modernisation of Labour Law (Kluwer Law International The Hague 2002)

Van Niekerk 2005 CLLJ

Van Niekerk A "Employees, independent contractors and intermediaries:

The definition of employee revisited" 2005 Contemporary Labour Law Journal 11-20

Van Niekerk and Christianson Law @work

Van Niekerk A and Christianson M (eds) Law @work (LexisNexis Durban 2008)

Webster and Bezuidenhout 2005 http://www.sarpn.org.za/ 27 Nov Webster $E$ and Bezuidenhout A "Debating the flexible world of work in South Africa" in Edigheji O (ed) Trajectories for South Africa: Reflections on the ANC's National General Council (SARPN Pretoria 2005) [Found on 
internet] http://www.sarpn.org.za/documents/d0001326/index.php [Date of use 27 November 2008]

\section{Register of cases}

\section{South Africa}

Transport and General Workers Union \& another v Bayette Security Holdings 1999 ILJ 1173 (LC)

Louw v Golden Arrow (Pty) Ltd 2000 ILJ 188 (LC)

Mahlangu v Amplats Development Centre 2002 ILJ 910 (LC)

Amazulu Football Club v Hellenic Football Club 2002 ILJ 2357 (ARB)

Building Bargaining Council (Southern and Eastern Cape) v Melmons Cabinets 2001 ILJ 120 (LC)

Coetzee $v$ Commits \& others 2001 ILJ 331 (C)

LAD Brokers (Pty) Ltd v Mandla 200122 ILJ 1813 (LAC)

Mans v Mondi Kraft Ltd 2000 ILJ 213 (LC)

Midway Two Engineering \& Construction Services BK v Transnet Bpk 1999 ILJ 738 (SCA)

Motor Industry Bargaining Council v Mac-Rites Panel Beaters and Spray Painters (Pty) Ltd 2001 ILJ 1077 (N)

Medical Association of SA \& others v Minister of Health \& another 199718 ILJ 528 (LC)

Niselow v Liberty Life Association of SA Ltd 1998 (4) SA 163 (SCA)

S v Makwanyane 1995 (3) SA 391 (CC)

SA Broadcasting Corporation v McKenzie 199920 ILJ 585 (LAC)

Borcherds v CW Peace \& F Sheward t/a Lubrite Distributors 199112 ILJ 383

(IC)

South African National Defence Union v Minister of Defence 19994 SA (CC) NUMSA \& others v Gabriels (Pty) Ltd Case 523/2001 (LC) 2 December 2002 (unreported)

\section{The European Court of Justice}

Bilka-Kaufhaus GmbH v Weber von Hartz [1986] 2 CMLR 701 
Jenkins v Kingsgate (Clothing productions) Ltd [1981] 2 CMLR 24

\section{Register of legislation}

Basic Conditions of Employment Act 3 of 1983

Basic Conditions of Employment Act 75 of 1997

Constitution of the Republic of South Africa 1996

Employment Equity Act 55 of 1998

GNR 1774 Government Gazette 294551 December 2006

Labour Relations Act 66 of 1995

Occupational Health and Safety Act 85 of 1993

Promotion of Equality and Prevention of Unfair Discrimination Act 4 of 2000

Skills Development Act 97 of 1999

\section{Register of directives and other international documents}

Declaration on Fundamental Principles and Rights at Work of 1998

EEC Treaty

Treaty of Amsterdam

African Charter of Human and Peoples' Rights 1981

Freedom of Association and Protection of the Right to Organise Convention 87 of 1948

Homework Convention 177 of 1996

Employment Relations Recommendation 2006

Employment Relationship: An annotated guide to ILO Recommendation No 198

International Covenant on Economic, Social an Cultural Rights 1996

Maternity Protection Convention 183 of 2000

Part-Time Work Convention 175 of 1994

Recommendation of Part-Time Work 182 of 1994

Rural Workers' Convention 141 of 1975

Workers with Family Responsibilities Convention 156 of 1981

\section{European Directives}


Employer's obligation to inform employees on conditions applicable to the contract or their employment relationship Directive 1991

Equal Pay Directive 75/117/EEC

Equal Treatment for Part-Time Workers Directive 1997

Equal treatment with regard to working conditions Directive 76/207/EEC

Fixed-Contract Work Directive 1999

Framework Agreement on Part-time Work Council Directive 97/81/EC

Mutual recognition of diplomas, certificates and other formal qualifications of self-employed persons Directive 1989

Occupational pension schemes Directive 86/378/EEC

Organisation of work time Directive 93/104/EEC

Prohibition of discrimination in statutory social security schemes Directive 79/7/EEC

Safety and health at work of pregnant woman Directive 92/85/EEC

\section{Register of internet sources}

Department of Labour 1996 http://www.info.gov.za/ 27 Nov

Department of Labour 1996 Green Paper on Labour: Minimum Standards Directorate Policy Proposals for New Employment Standards Statute Green Paper [Found on internet] http://www.info.gov.za/greenpapers/1996/labour. htm [Date of use 27 November 2008]

EURLex http://eur-lex.europa.eu/en/index.htm 2 Aug

EURLex 2008 Overviews of the European Union Activities Employment and Social Affairs [Found on internet] http://eur-lex.europa.eu/en/index.htm

[Date of use 2 August 2008]

ILOLEX http://www.ilo.org/ilolex 4 Aug

ILOLEX 2008 Database of International Labour Standard [Found on internet] http://www.ilo.org/ilolex [Date of use 8 August 2008]

\section{List of abbreviations}




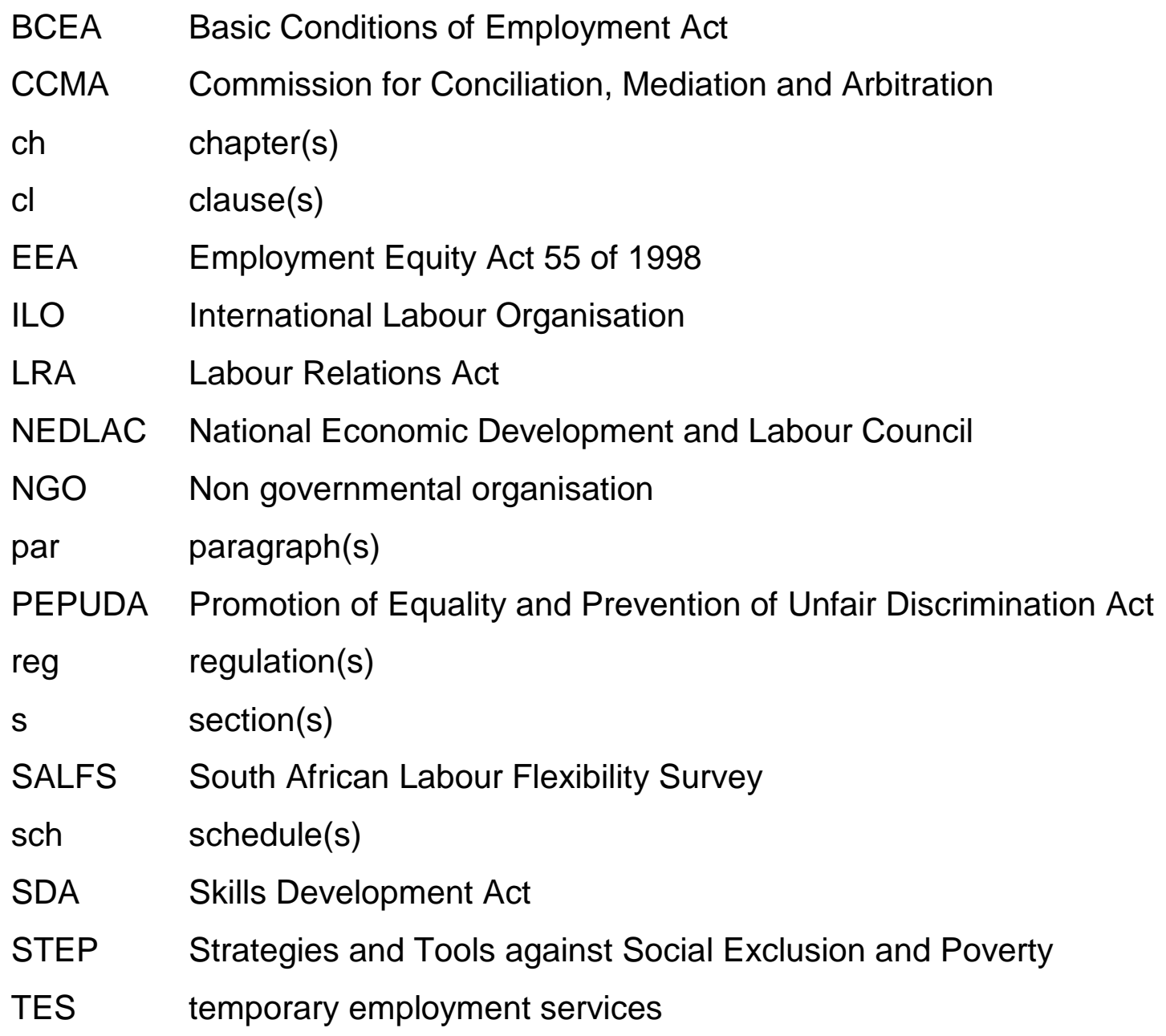

